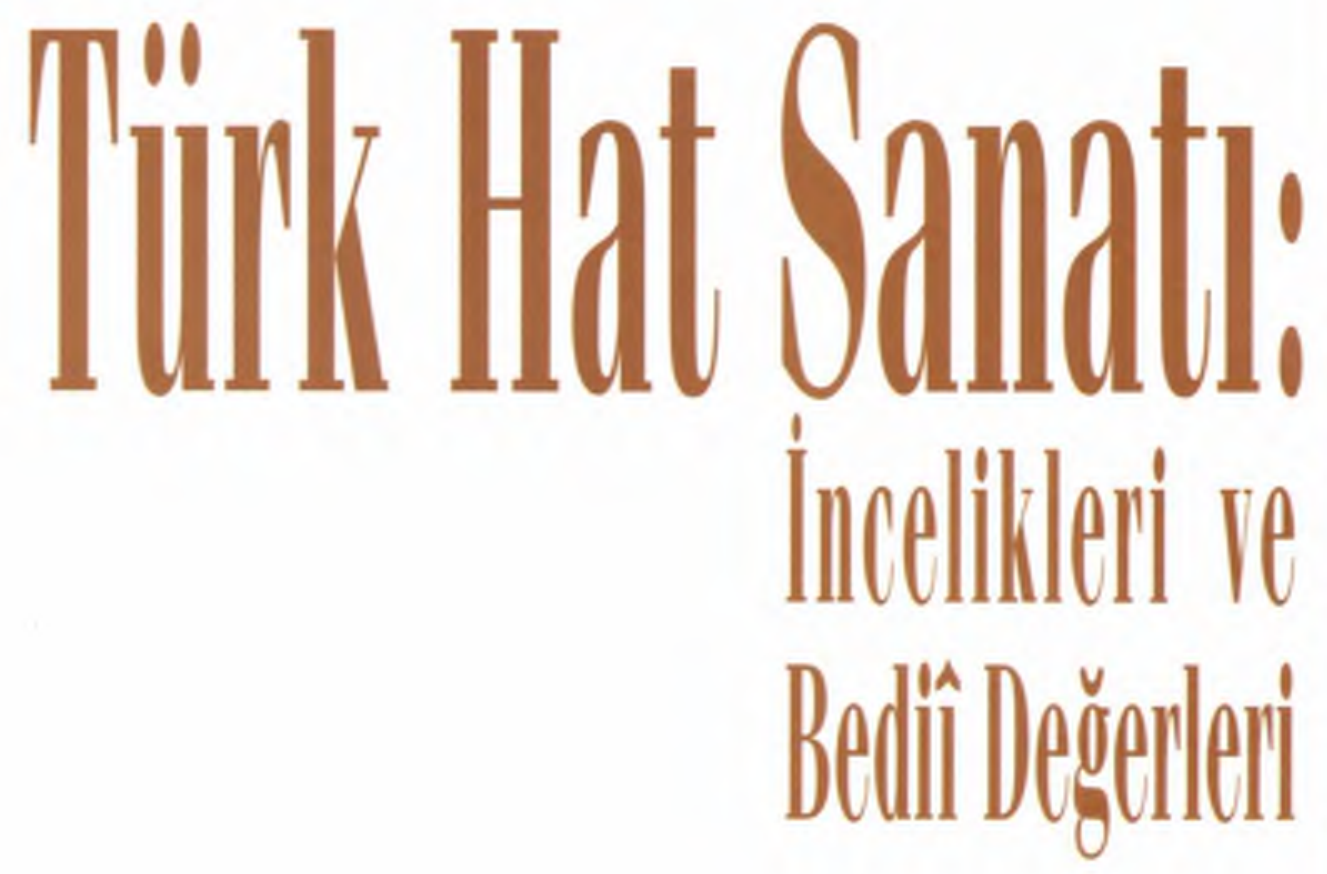

\section{Uğur Derman*}

"Türk Hat Sanatı" ifâdesi bir iddiayı da beraberinde getirmiş oluyor. Çünkü bahis konusu harfler, ash îtibariyle Türk'e ait değil; Araplar'ın Nabatî kavminden alıp benimsedikleri ve Islâm'in zuhûrundan ancak iki asır sonra sanat hüviyeti kazandırdıkları bir okuma-yazma vâsitası... Türkler, Islâmiyet'i kabul edişlerinden sonra tanıştıkları bu yazı sistemiyle, zaman içinde o kadar içlidışı olmuşlar, onu öylesine sevmişler ki, "Türk Hat Sanatı" kavramı son beş asırdır mübalağadan uzak bir tesbiti aksettirmekte ve bu üç kelime birlikte pek yaraşmaktadır.

"Sanat" vasfını kazanmış bulunan bazı meslekler, asıl gayeleri îtibariyle insanlığa fayda sağlayan bir vazifeyi de yerine getiriyorlarsa, muhakkak ki ehemmiyetleri çok daha artmaktadır. Bu cümleden olarak, herşeyden önce Islâm âleminin okuma-yazma ihtiyacını da gidermeyi gaye edinen hüsn-i hattın (güzel yazının) ortaya çıkışı dînî mâhiyette sayılır. Çünkü hat sanatına bu kadar kıymet verilmesi, Kur'ân-1 Kerîm'in mushaf hâlinde yazıya aktarılmasında ona yakışan bediî güzelliği arayıp bulmak gayretiyle başlamış, gündelik yazışmalardaki sanat tezâhürü daha sonraları belirmiştir. Batı'ya hükmeden Rönesans hareketinin de dînî konularla doğduğu ve uzun müddet böyle sürdügü hatırlanırsa, bunu olağan karşılamak gerekir.

Islâmîyeti kabul eden hemen hemen bütün kavimlerin -herşeyden önce- dînî gayretle benimsemiş olduklan Arap yazısı, bu sebeple, Hicret'ten (622) birkaç asır sonra artık bir milletin değil, bütün Islâm ümmetinin ortak malı hâline gelmiş; ash ve başlangıcı için doğru olan "Arap hattu" sözii de zamanla şumûlünü genişleterek, en hakkâniyetli târifiyle "Islâm hattı" vasfını kazanmıştır. Esâsen, hattın sanat olarak gelişmesi, XIV. asırdan îtibaren Arap kavmi dışındaki Müslüman milletlerde daha belirgin bir mertebede hissedilmekte, bu hususta Osmanlı Türkleri de başı çekmektedir. Hat sanatı Osmanlılarca bir ilâhî emanet gibi alındıktan sonra, asırlarca süren bir süzülüp arınma ve üslûplaşma hareketine girişilmiş; bütün bunlar yazının esasını bozmadan yapılmıştır.

Islâm tarihi boyunca Şam, Bağdad, Kurtuba, Kãhire, Konya, Semerkand, Herat, Tebriz gibi taht merkezlerinde hükmünü sürdüren devlet ve hânedanlann (Emevî, Abbâsî, Fâtımî, Eyyûbî, Memlûk, Selçuklu, Ilhanlı, Tìmurî, Safevî, Akkoyunlu...) devrinde daima ilgi çekici bir sanat olarak görülen hüsn-i hat, buna meraklı hükümdar veya devlet büyüklerinin himâye ve alâkasıyla yükselişini sürdürmüştür. Istanbul'un fethini müteâkip hat sanatının liderliğini alarak bunu beş asra yakın devam ettiren Osmanlı Devleti'nin hükümdarlarnndan yedisinin fiilen bu sanatla meşgul oldukları bilinir (Resim 1). Istanbul'un hüsn-i hatta böylesine bağlanışı Islâm âleminde de şu sözlerle tescil edilmiştir: "Kur'ân-1 Kerîm Hicâz'da nâzîl oldu, Mısır'da okundu, Istanbul'da yazıldı”. Gerçekten, o mushafları (Resim 2) görüp de, Islâm hattına Kur'an-1 Kerîm’in süregelen bir mûcizesi nazarıyla bakmamak imkânsızdır. Bunun dışında, dîvânından fermânına, mermer üstüne hâkkedilmiş çeşme kitâbesinden mezar taşma kadar her bir eser, isimlerini burada ayrı ayrı yâdetmeye imkân bulunamayan hat sanatkârlan tarafindan, Istanbul'un ismine lâylk bir biçimde, güzelliği görebilenlerin nazarlarına sunulmuştur.

Hat, bu sanata âşinâ bir insanın elindeki kamış kalem (Resim 3) ve onun damarındaki kan mesâbesinde olan is mürekkebinin işbirliğiyle kağıd veya benzeri bir yazı sahasında husûle getirilir. Harflerin bünyesi, hat nev'ine göre, yazıldığı kalemden çıkan eşkenar dörtgen veya kare şeklindeki noktalarla ölçülendirilir (Resim 4). Harflerin boylarının, kavislerinin, meyillerinin, aralarındaki mesafenin tâbi olduğu ölçü birimi dâima bu noktanın

* Prof. h.c., Mimar Sinan Üniversitesi Güzel Sanatlar Fakültesi Öğretim Üyesi. 


\section{The Art of}

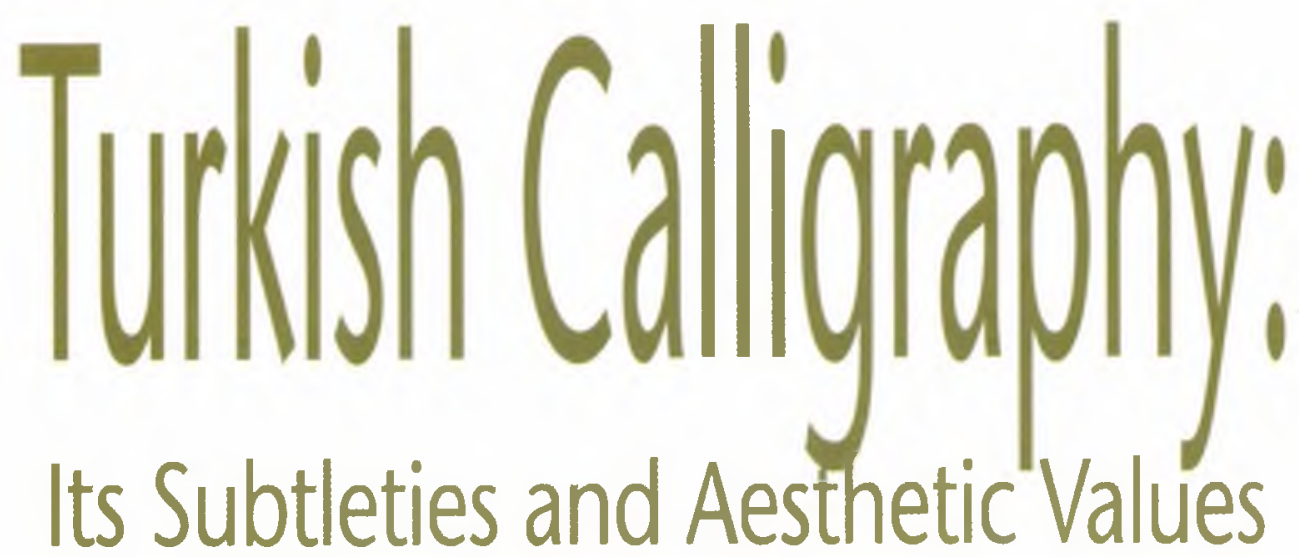

\section{Uğur Derman*}

Translated by Semiramis Çavuşoğlu

The expression of "the art of Turkish calligraphy" carries a claim within itself for the letters used in this art do not belong to the Turks originally. The Arabs took these letters from the Nabataean people and gave them an artistic identity two centuries after the emergence of Islam. The Turks were acquainted with this writing system after embracing Islam. In time, they were so fond of it that the concept of "the art of Turkish calligraphy" has been used without any exaggeration for the last five centuries.

* Prof. h.c., Mimar Sinan University, Faculty of Fine Arts.

Without doubt, the importance of some professions which bear the characteristics of an "art" increases even more if they essentially aim to fulfill the important purpose of serving the humanity. As a case in point, calligraphy whose primary purpose has been to meet the needs of the Muslims to read and write, turned into

Resim/Picture 1

Sultan II. Mahmud'un (1785-1839) celî sülüs levhası (Topkapı Sarayı Müzesi Kütüphanesi).

A plate in jali thuluth by Mahmud II (1785-1839). (Topkap Palace Museum Library)

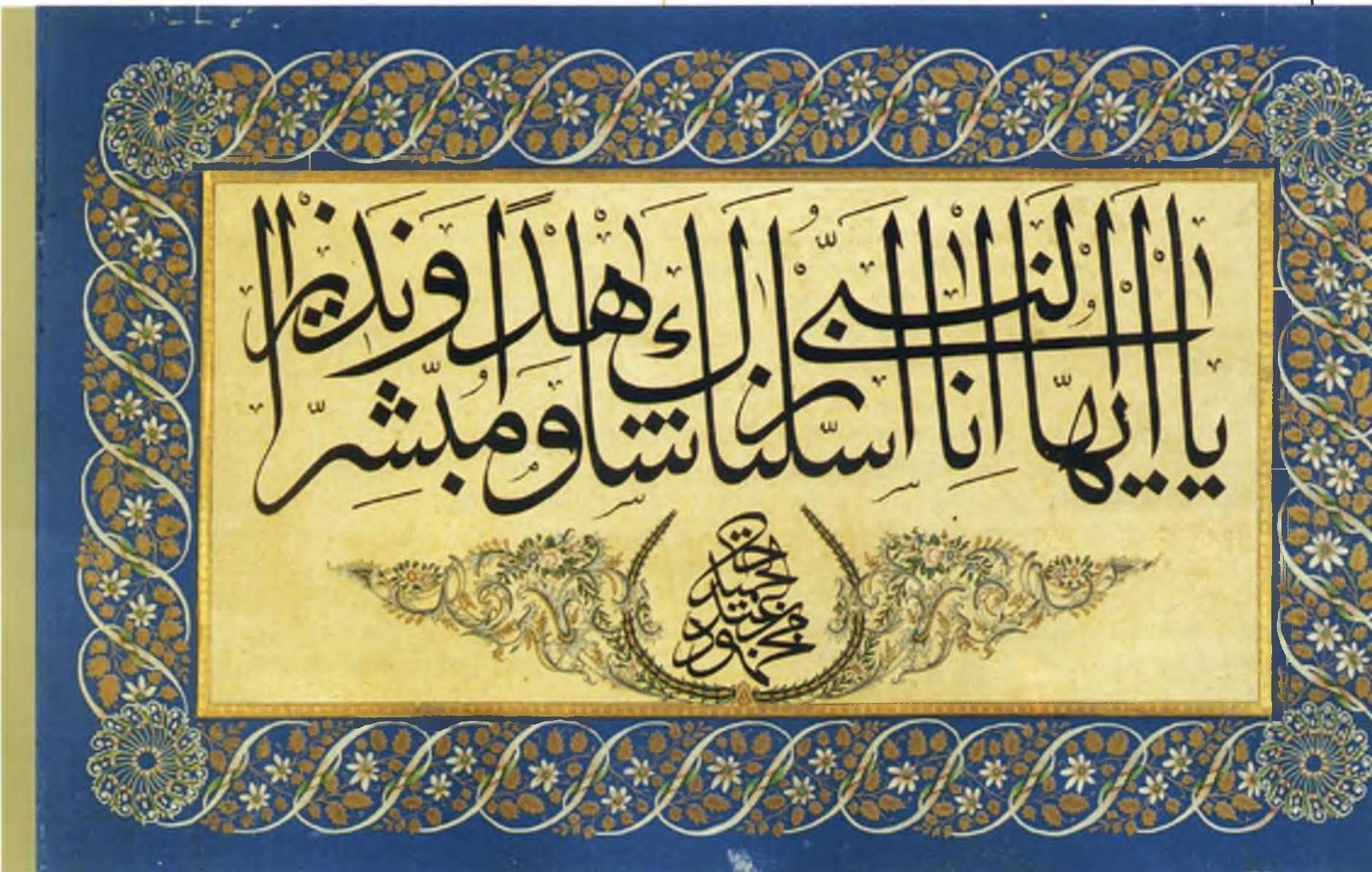




\section{Resim/Picture 3}

Hüsn-i hattın yazılmasında kullanılan kamıș, bambu veya ağaçtan hazırlanmış kalemler (Derman Arşivi).

Reed, bamboo and wooden pens used in calligraphy (Archives of Derman).

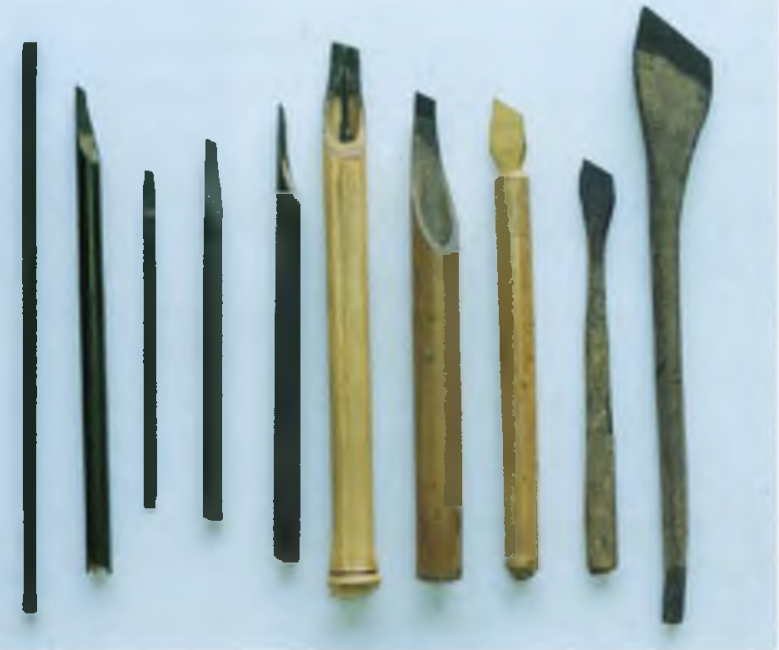

an independent art owing to the efforts encouraged by Islam. At first, calligraphy was used in copying the Holy Qur'an in the form of mushafs in an aesthetically pleasing way. Later on, daily correspondence was calligraphed with artistic considerations. The reader should not be surprised at the fact that this art emerged with a religious nature and continued this way for a long time. In fact, the arts which emerged in the West during the Renaissance dealt with religious subjects and carried this influence for centuries.

Almost all peoples which embraced Islam adopted the Arabic script-above all-because of religious perseverance. For this reason, a few centuries after the Hegira (622) the Arabic script became the common asset not only of a nation, but of the entire Islamic community; the term "Arabic script" which was used correctly to denote the essence and origin of this script was later expanded in meaning to be defined most correctly as "Islamic calligraphy". From the fourteenth century onwards, the development of calligraphy as an art was felt more evidently among Muslim nations other than the arabs and particularly among the Ottoman Turks. It was the Ottomans who considered the art of calligraphy as a sacred relic and subjected it to a movement of selection and stylization without spoiling the essential characteristics of this script.

Throughout Islamic history, the states and dynasties such as the Umayyads, Fatimids, Ayyubids, Mamluks, Seljukids, Ilkhanids, Timurids, Safavids and the Aqqoyunlus reigned in centers such as Damascus, Baghdad, Cordoba,
Cairo, Konya, Samarqand, Herat and Tabriz. In these centers rulers and dignitaries of the state took an interest in calligraphy and protected the calligraphers. After the conquest of Constantinople, the Ottomans became the leaders in the art of calligraphy and kept this position for nearly five centuries. In fact, seven Ottoman sultans actually practiced this art (illustration 1 ). The following words clearly indicate the leading position of Istanbul in regard to calligraphy: "The Holy Qur'an was revealed in the Hijaz, it was recited in Egypt and calligraphed in Istanbul". Indeed, when one sees those mushafs, (illustration 2) one believes that Islamic calligraphy is a miracle of the Holy Qur'an-a miracle that still exits today. Besides the mushafs, one also sees Islamic calligraphy in dîwãns (collection of poetry), fermãns (imperial decrees), on the inscriptions of fountains and tombstones in Istanbul.

\section{Resim/Picture 4}

Yesârî Mehmed Es'ad Efendi'nin noktayla ölçülendirerek 1200/1785'de yazdığı bir ta’lîk temrini (Ârif Hikmet Bey Kütüphanesi-Medîne).

An exercise sheet (tamrîn) in ta'î́q by Yesãrî Mehmed Es'ad Efendi which he wrote in 1200/1785 by measuring with the rhomboid dots. (Arif Hikmet Bey Library-Medina).

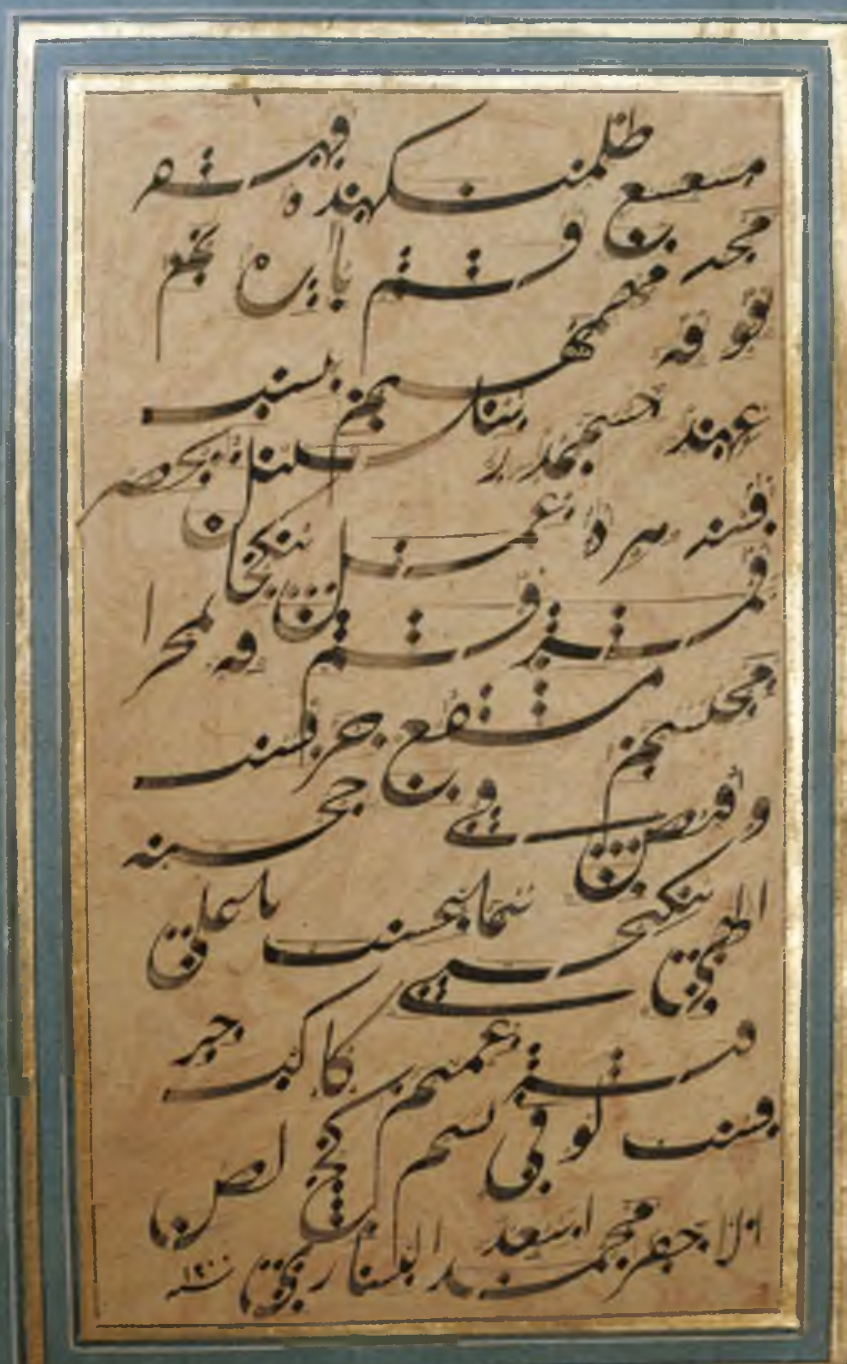


bilinen altı nevi yazı) anlayışı Anadolu'da da geçerliydi. Ancak Amasyalı Şeyh Hamdullah (1429-1520), 1485'den sonra İstanbul'da - Yâkut'un harflerinden en güzellerini seçerek -ortaya koyduğu üslûpla aklâm-ı sitteye Türk damgasını vurmuş oldu ve ondan sonra bütün Osmanlı topraklannda "Şeyh üslûbu" yaygınlaştı (Resim 2). Yine XVI. asırda, Ahmed Karahisârî (1469-1556), Yâkut yolunu tekrar canlandırmaya çalıştıysa da (Resim 10), bu yol ancak bir hattat nesli yürütülebildi. Bu defa XVII. yüzyılın son çeyreğinde, Hâfız Osman (1642-1698) isimli bir hat büyüğü, aklâm-ı sitteyi eleyip arındırma faaliyetini Şeyh üslûbu için gerçekleştirdi. (Resim 7, 11). Bu gelişmeden hemen sonra aklâm-ı sittenin düzlük hâkim olan çeşitleri (muhakkak, reyhânî) Türk zevkiyle bağdaşmadığı için terkedildi. Zâten Osmanlı mimârisinde ağır basan yuvarlak çizgiler, hat sanatında da hâkim olduğundan Osmanlı Türkleri k̂uffi gibi sert çizgili yazılara fazla iltifat etmemişlerdir.
Sülüsü andıran ve on altıncı asra kadar resmî yazışmalara aynılmış olan tevkî̀ hattı da, vazifesini dîvânî ve celî dîvânî (bunun celî vasfi büyüklüğünden değildir) isimli iki Türk yazısına bırakınca, aklâm-ı sittenin sâdece üçünün Osmanlılar'da kullanılması sürdürüldü. Bunlardan sülüs ve onun uzaktan okunabilecek kalınlıtaki celî sülüs şekli sanat göstermeye en ziyâde müsâid olanlandır. Hattun, çoğu zaman satur hâlinde yazılmasına mukābil, celî sülüste istif endișesi, yani harf ve kelimelerin bir kâide dairesinde üst üste terkip edilmesi lüzûmu baş gösterir (Resim 6). Istif tertîbinde, ekseriya așağıdan yukarıya doğru iki-üç katlı bir sıralama takip edilir; harf ve kelimeler okunuşa göre başarıyla yerleştirilmişse, bu yazının "teşrifâtı yerinde"dir. Osmanlı hattatları, Kur'ân âyetlerinin hatâlı okunmasına meydan vermemek için, bu teşrîfat mes'elesine anadili Arapça olan diğer Müslüman milletlerden fazla riâyet etmişlerdir. Resim terbiyesi almış bulunan hattatların istif hususunda daha muvaffak

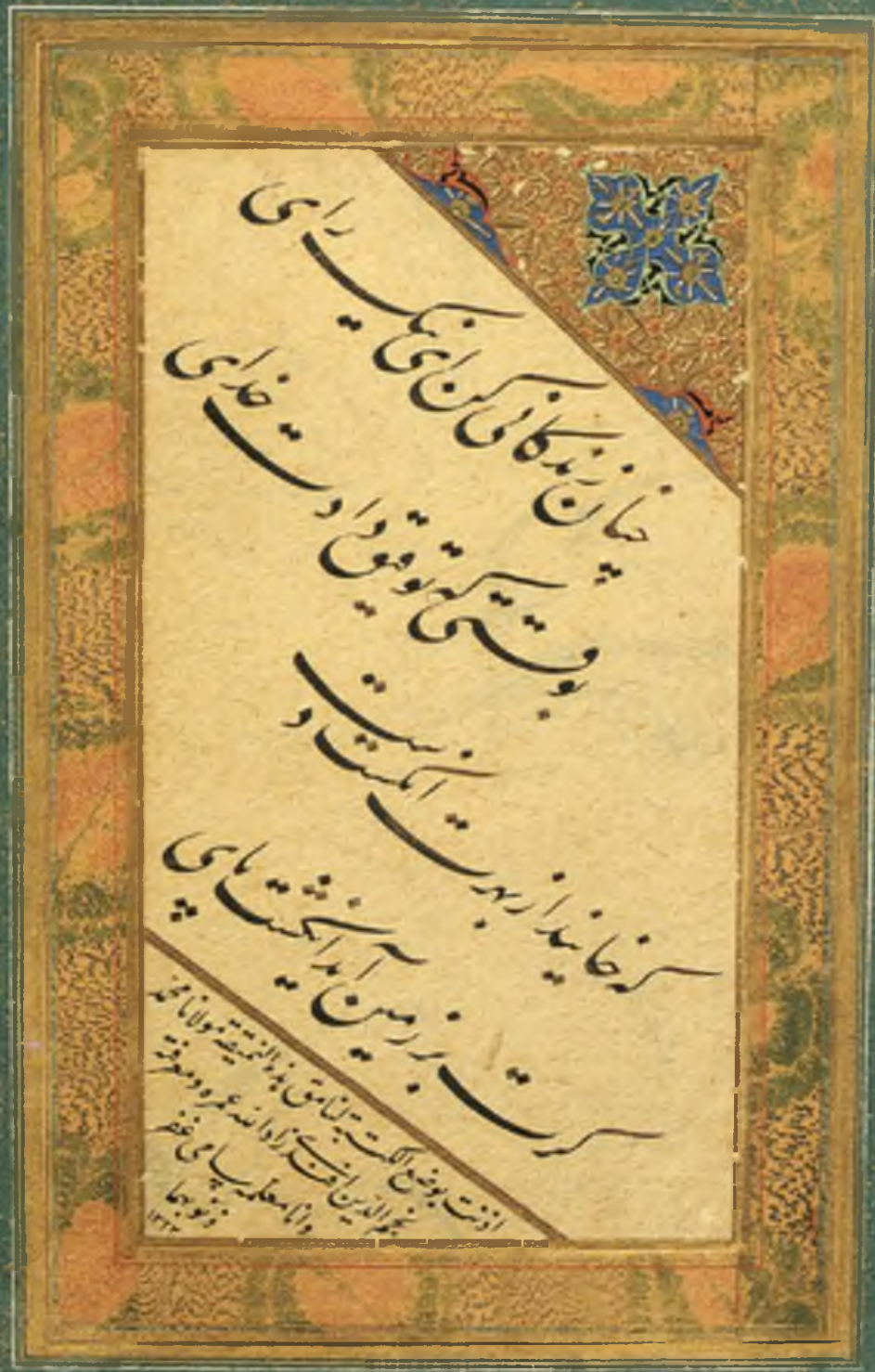

\section{Resim/Picture 8}

Necmeddin Okyay'ın (1883-1976), İmâdü'l-Hasenî'ye taklid olarak yazdığı ve Hocası Sâmi Efendi'den aldığı ta'likk icâzet kıt'ası (1323/1905, Derman Arşivi).

An icãzet kıt'a (certificate) in ta'lia , dated 1323/1905, which Necmeddin Okyay (1883-1976) calligraphed in order to emulate Imãd al-Hasanî. His teacher Sãmi Efendi gave this certificate to Necmeddin Okyay (Archives of Derman)

Ahmed Karahisârînin celî sülüs, sülüs, muhakkak, gubârî hatlan ile bir kut'ası (Süleymaniye Kütüphanesi).

A kit'a by Ahmed Karahisãrî in jalî thuluth, thuluth, muhaqqaq and ghubârî scripts. (Süleymaniye Library). 

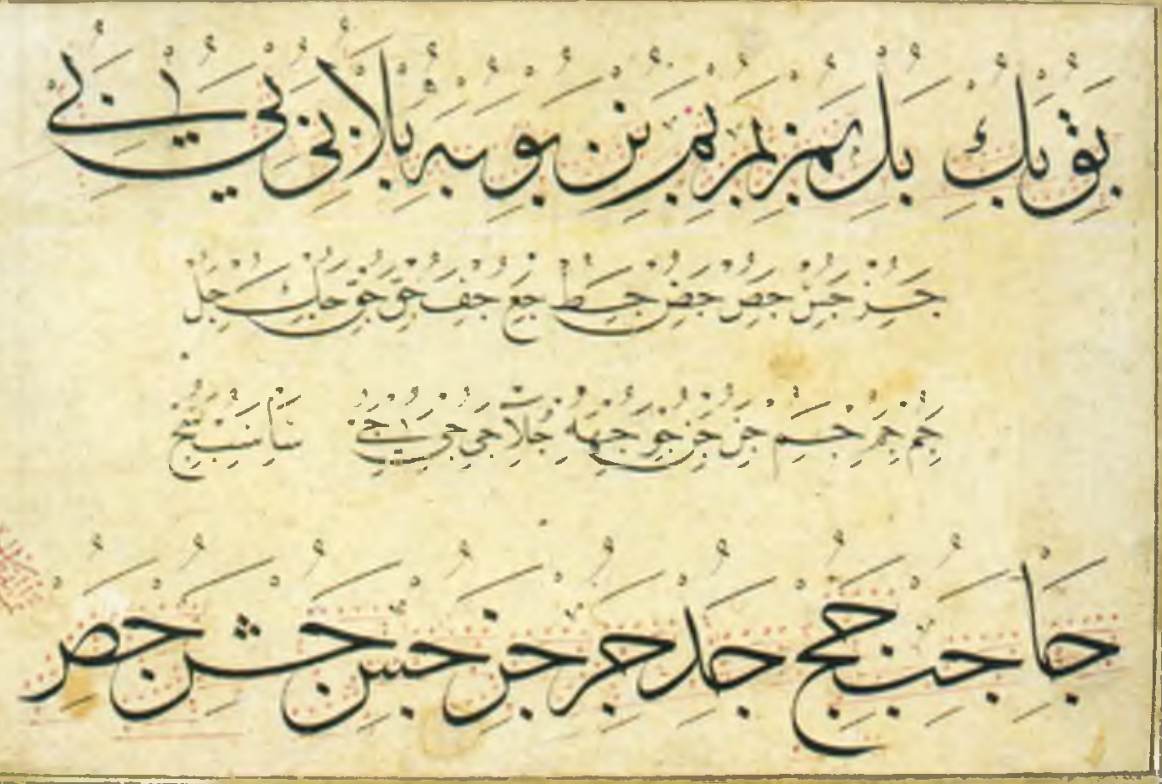

Resim/Picture $\mathbf{9}$

Mustafa Râkım Efendi'nin bir ögrencisi için yazdığı, iki harfin bitișme şekillerini gösteren (müfredât) sülüs-nesih meşk1, sülüs harfleri lâl mürekkebiyle ölçülendirilmiştir (Topkapı Sarayı Müzesi Kütüphanesi).

A thuluth-naskh meşk by Mustafa Räkım Efendi which he wrote for one of his pupils. This meşk is a mufradät (letters incombination with one other letter). The letters in thuluth were delineated with red ink of ruby color. (Topkapı Palace Museum Library).
The calligrapher produces his works by using a reed pen (illustration 3 ) and soot ink on a paper or a similar surface. According to the kind of the script, the size of the letters are measured by rhomboid or quadratic dots produced by the pen (illustration 4). The size of the dot depends on the width of the pen's nib. The width, length and position of each letter is calculated by taking the dot as a unit. The length of the letters is measured with reference to the length of a dot; that is, the diagonal measure from corner to corner. Thus, the simple system of lines consisting of dots creates a geometry that wins the admiration of the beholder. In any piece of writing that is regarded as a work of calligraphy the length of the lines and the spaces between them are calculated by means of dots. Calligraphers may not always adhere too strictly to these measurements, which emerged in a long time as a result of the search for beauty, but when they deviate from the norm, they do not do so arbitrarily. Otherwise, the proportions the scripts have attained over the years will be distorted.

In the art of calligraphy, aesthetic concepts are expressed only by black lines on a slightly colored

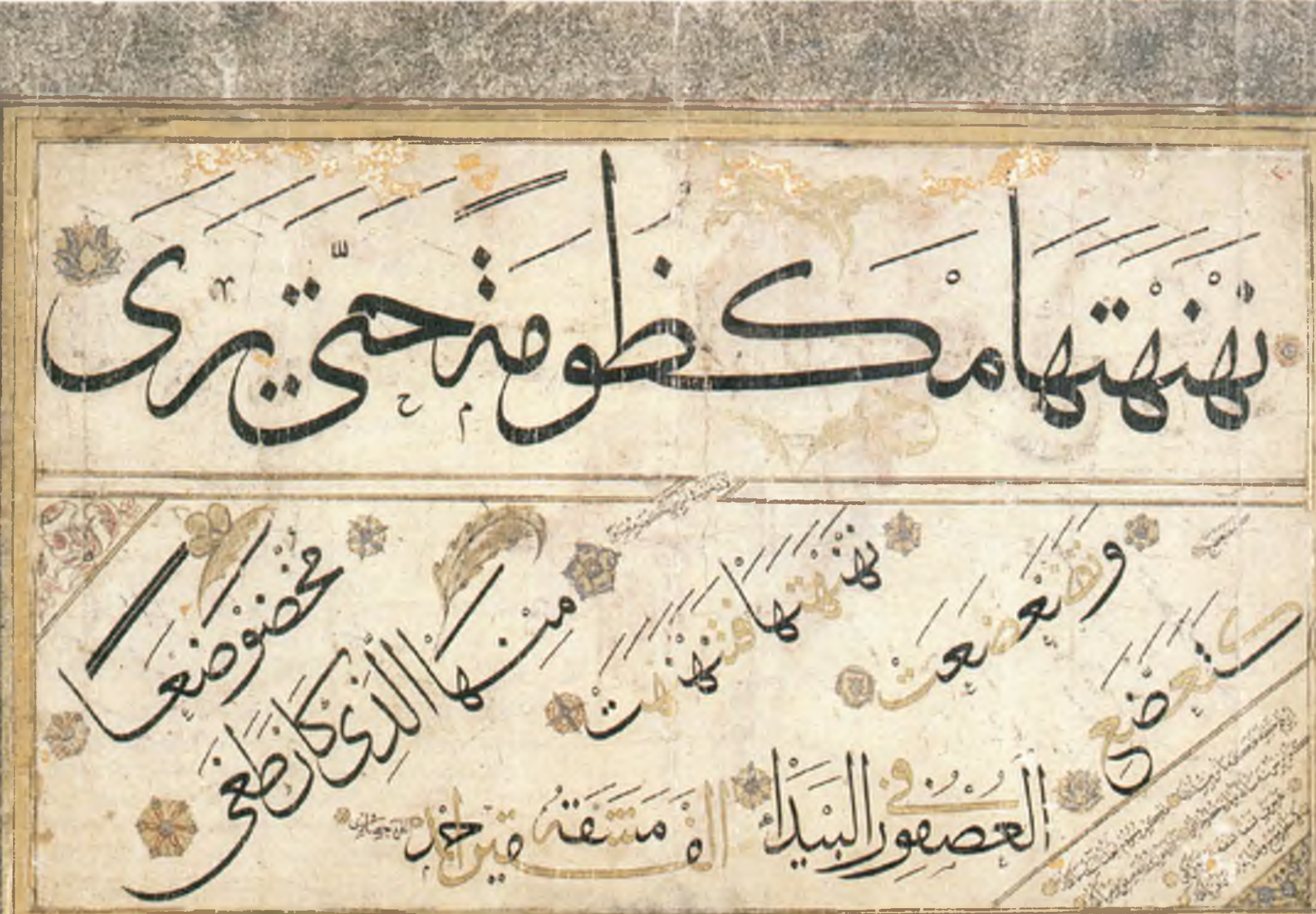


background. Western painters were interested in and inspired by this art since this kind of expression is not seen in other letter systems. From this viewpoint, calligraphy should not be considered as a simple work below the level of drawing. On the contrary, it is a highly artistic product that is beyond drawing. In calligraphy, each letter by itself is an expression of absolute beauty. Each letter is written differently according to its position in the beginning, in the middle or at the end of the word (illustration 5) and some letters can be elongated. Calligraphers arranged the letters in different ways and created charming compositions (illustration 6). The letters of the Latin alphabet are static and the alphabets of the Far Eastern countries consist of separate groups of letters made of aesthetic lines. Islamic calligraphy is superior to these alphabets in regard to the harmony of the letters. It is indeed a separate, distinct and original art form. The use of calligraphy in daily life as a means of reading and writing led to the development of aesthetic concepts in the minds of people. The measurement system of the letters led to a sense of orderliness.

The art of calligraphy emerged and developed by way of imitation. Therefore, in the beginning, the pupil did his best to emulate his master and the school to work. Thus, the imitated work looks precisely the same as the original, but, in imitative calligraphy, it should be noted, the original was never copied by tracing (illustration 7). The pupil receives his certificate (icãzetnâme) from his master after having emulated an old master's work (illustration 8).

The most important elements in making calligraphy an art the pupil who learns it from his master by an example (meşk) (illustration 9) and the reed pen. The way a calligrapher holds it and turns it in his hand and the way he applies the nib of the pen to the paper determines the excellent arrangement of the letters or the letter groups. The width of the pen's nib is determined for every kind of script. (For example, approximately 1 $\mathrm{mm}$. for naskh and 2-2,5 $\mathrm{mm}$. for thuluth and ta'liq). When it is larger, the script is called jali.

Resim/Picture 13

Sâmi Efendi'nin ihtiyarlığında zırnık mürekkebiyle yazdığı enfes bir celî sülüs taslağı (Derman Arşivi). An outline written with yellow arsenic ink in splendid jaî thuluth by Sãmi Efendi in his old age. (Archives of Derman).

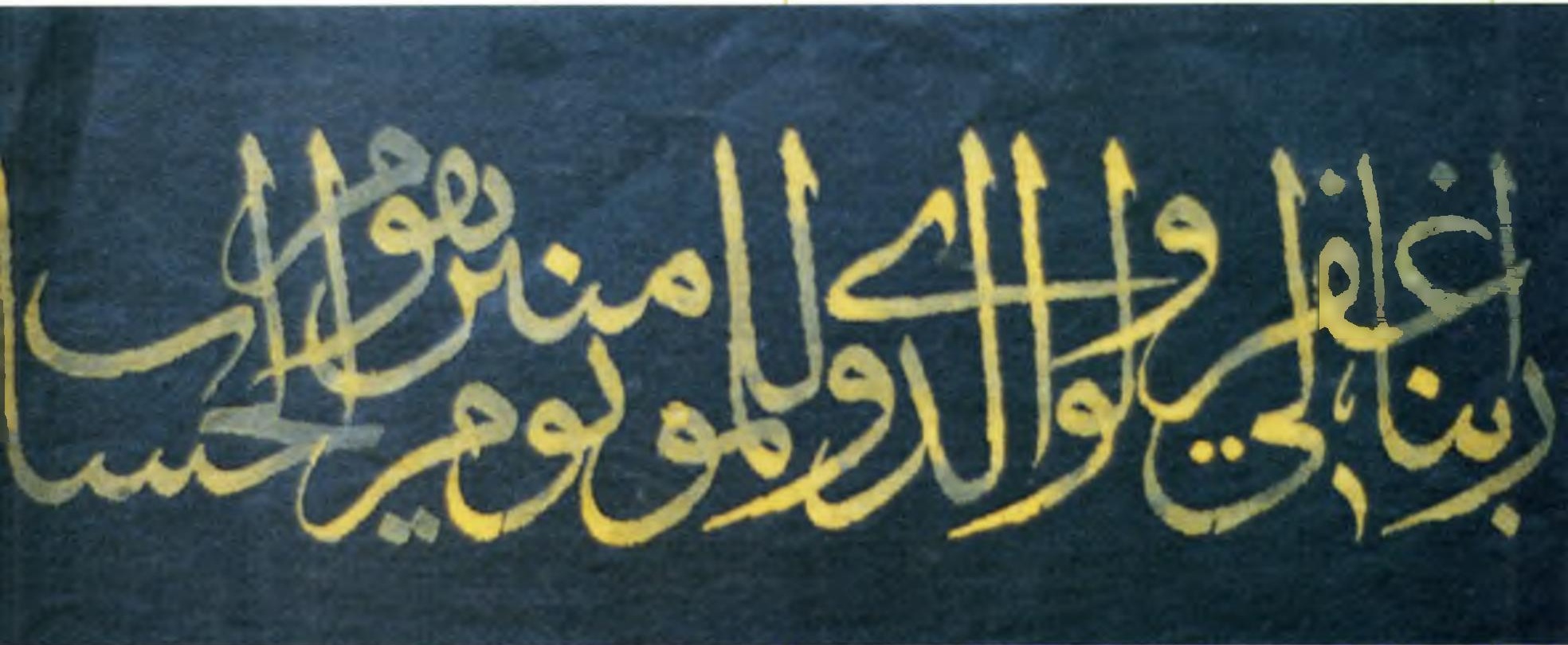

which his master belonged. But, in later centuries, each new calligrapher preferred to express his own artistic identity. A calligrapher, who has reached this point, considered it an honor to emulate his own master or an old master and to acknowledge this in his work. In imitation, the calligrapher registers the piece to be copied in his memory and copies the work on paper as if he were taking a photograph. One sees several specimens of imitated works in the art of Turkish calligraphy. In fact, imitation is much more difficult to achieve than one can imagine. The calligrapher thoroughly examines the style of the master before he starts to emulate his
Although there have been several kinds of scripts in Islamic civilization, the Ottoman taste selected those which were most suitable for artistic usage. These are: Thuluth, jalî tuhuluth, naskh, riqã, (icãzet), ta'lîq, dîwãnî, jalî dîwãnî, riq'a (handwriting) and the tuğra. Calligraphy reached perfection in the Seljukid and the Ottoman periods until about the end of the fifteenth century. However, concerning the style, it still depended on the developments during the Abbasid period. In this regard, Yãqût al-Musta'simî (d.1298), the great figure who lived in Baghdad in the thirteenth century, identified the aqläm-i sitta or six pens (thuluth-naskh-muhaqqaq-rayhãnî- 


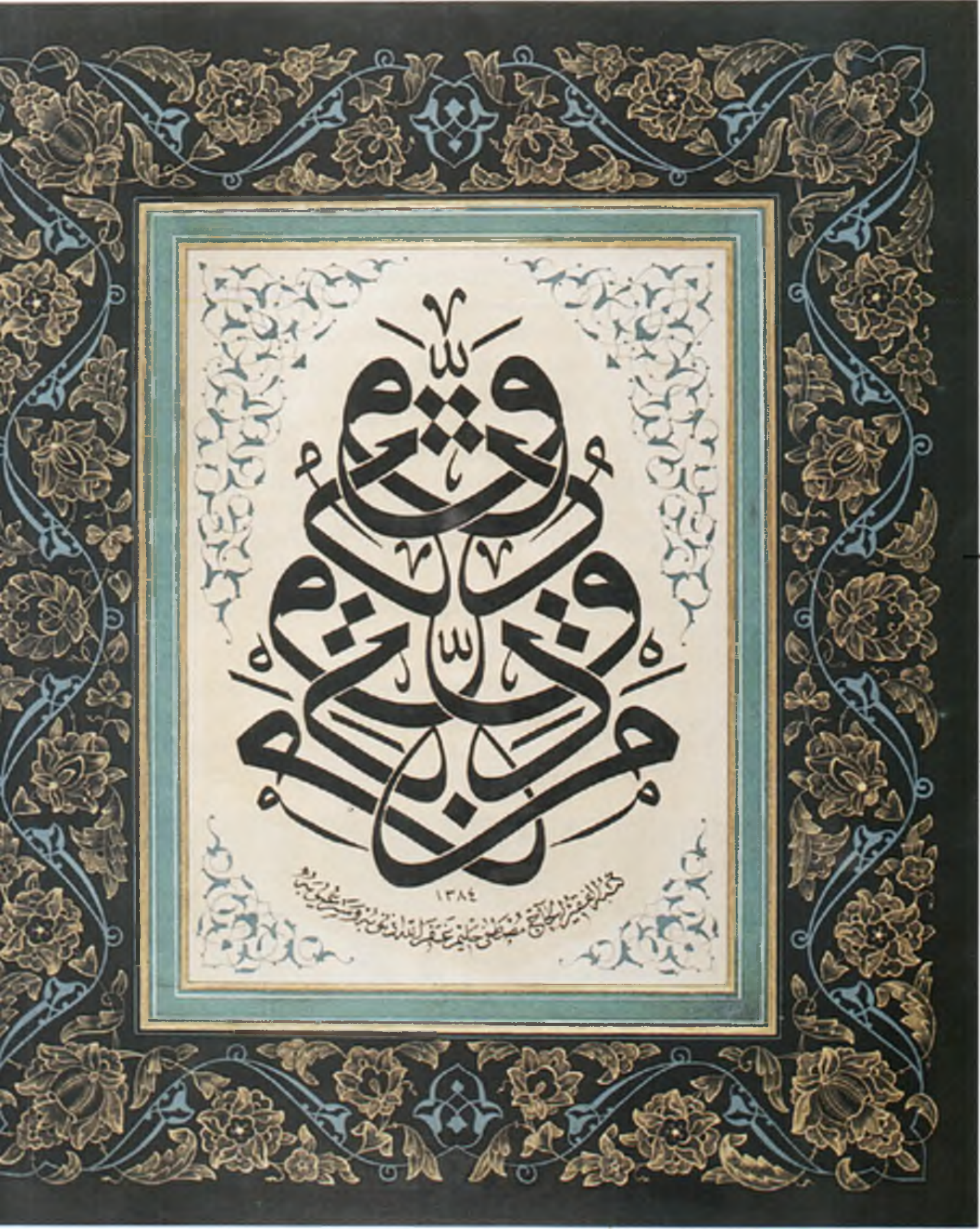

\section{Resim/Picture 14}

Mustafa Halim

Özyazıcı'nın (1898-1964)

celî sülüs le müsennâ istifi:

"Men dakka dukka"

(=Çalma kapıyı; çalarla kapını). 1384/1964 tarihli levhanın tezhîbi. F. Çiçek Derman'indır (Derman Arşivi).

\section{A mirror-image}

composition dated 1384 1964: "Men dakka dukka" (Don't cause trouble or you will have trouble). The illumination was done by Mrs. Çiçek Derman (Archives of Derman).
(1801-1876) ve Mehmed Şevki (1829-1887) efendiler gibi iki büyük üstâdın elinde farklı üsluplarda nihâî şeklini almıştır (Resim 15-Resim 16).

Osmanlı kültüründe müstesnâ yeri olan bir başka hat nev'i de ta'liktir. Aslı İran'da nesta'lik adıyla bilinen ve XV. yüzyıldan beri Osmanlılar'da görülen bu yazı -sülüs ile celî sülüsün haşmetine mukâbil- nârin yapısıyla, XVII. asnn ortalarına yaklaşırken Istanbul'da daha da yayılmaya başlamış; harekesiz yazıldığı cihetle, edebî metinlerde ve meşîhat dâiresinde tercih edilmiștir. XVIII. yüzyılın son çeyreğine kadar Iran'ın mâruf hattatı Mîr Imâdư'l-Hasenî (1564-1615) vâdisinde yazılıyorken, sağ tarafı felçli olduğu için sol eliyle eser veren Yesârî Mehmed Es'ad (?- 1798), Osmanlı'ya has bir ta'lik üslûbunu Imâd'ın yazılarından seçerek bulmuș (Resim 4), oğlu Yesarîzâde Mustafa Izzet (?-1849) bu tavrı daha da millileş̧irmiştir (Resim 17). Hele onun elinden çıan celî ta'likk binâ kitâbelerinin seyrine doyulmaz. Bu yazıı da evvelce anılan Sâmi Efendi'de kemâl noktasını bulmuştur (Resim 18).

Devlete mahsus yazılardan tuğra (Resim 7), dîvânî ve celî dîvânînin (Resim 19) de gelişmesini XIX. yüzyılda tamamladığını belirttikten sonra, başladığımız noktaya dönersek: Osmanlı hattatlan,

1) Batı'dan tesir almamakla benliğini koruyabilen hat sanatını, "üstad-talebe" mânevî ilişkisiyle öğreterek -maddî karşılık beklemeksizin- yeni nesillere aktarmayı asırlarca sürdürebildikleri;

2) "Allah güzeldir, güzelliği sever" hadîsini (Resim 18) her harfinde yașayarak yazmanın netîcesi, "mutlak güzellik" kavramını bu yazının çizgilerinde yakaladıkları için, onların torunları bugün "Türk Hat Sanatı" diyebilmenin hazzını duyuyor. 
tawqî'-riqã) and laid down their rules. After his death, his pupils carried on his work in Anatolia as well. However, after 1485, Şeyh Hamdullah of Amasya (1429-1520) selected the best letters in Yãqût's works and stamped the Turkish influence on the aqläm-i sitta in Istanbul. Afterwards, the "Şeyh's style" became widespread in the Ottoman lands (illustration 2). In the sixteenth century, another calligrapher by the name of the Ahmed Karahisãrî (1469-1556) attempted to revive Yãqût's style (illustration 10), but this attempt did not last for more than a generation of calligraphers. During the last quarter of the seventeenth century, Hãfız Osman (1642-1698), another great calligrapher, found his own style by the aesthetic evaluation of Şeyh's calligraphic works (illustration 7,11). Before long, muhaqqaq and rayhãnî were eliminated from the aqläm-i sitta because these scripts had few curved and rounded letters and they pointed angles such as the kûfi since the rounded lines which characterized Ottoman architecture were also dominant in calligraphy.

Until the sixteenth century, the tawqi' script, which is similar to thuluth, was used in official correspondence. From then on, it was replaced by two Turkish scripts called dîwãni and jali diwãnî (here the word jalî does not denote the size of the script). Thus, only three scripts in the aqläm-i sitta were used by the Ottomans. Among them, the ones that are most suitable for artistic usage are thuluth and jali thuluth. The latter is written with a pen of a very wide nib so that it can be read from a distance. Although calligraphy is generally written on lines, in jali thuluth the calligrapher has to arrange a composition (illustration 6), namely, letters and words are composed one above the other according to a principle. In the composition, the letters and words are generally arranged from the bottom to the top in two or three layers. In order to avoid any misreading of the Qur'anic verses, the Ottoman calligraphers took great care about composing the words and letters correctly.
In fact, they were more careful in this regard than other Muslim nations whose native tongues were Arabic. Let us note that calligraphers who were trained in drawing were more successful in arranging compositions. Mustafa Rãkım (1757-1826), who reached an unprecedented level in calligraphing thuluth in its jali form according to the style of Hãfız Osman, was also known as a painter (illustration 12). Mustafa Rãkım's style in calligraphy was further developed by Sãmi Efendi (1838-1912) (illustration 13) until it reached the present day. The Turks also used the mirror image (muthannã) form in which the same two passages in jali thuluth were facing one another and intersecting in the middle. It was not regarded as a separate kind of script, however (illustration 14).

The Ottomans mostly used the thuluth in artistic works, they devoted the naskh to mushaf writing, and the riqãa' (icãzet) script to writing the icãzetnãmes. In the nineteenth century, two Ottoman calligraphers by names of Kãdıasker Mustafa Izzet (1801-1876) and Mehmed Şevki (1829-1887) Efendis interpreted Hãfız Osman's works in different ways until the present day and perfected those types of the aqlãm-i sitta which are still used today (illustration 15-16).

$T a$ 'î is another important script in Ottoman culture. It originated in Iran by the name of nasta'liq and the Ottomans used it from the fifteenth century onwards. Contrary to the grandeur of thuluth and jali thuluth, ta'ifq has a delicate appearance and it became widespread in Istanbul towards mid-seventeenth century. Since it is written without vowel markers, ta'liq was preferred in literary texts and in the office of the Şeyhülislam. Until the last quarter of the eighteenth century, ta'liq was written in Istanbul according to the style of the renowned Persian calligrapher Mîr Imãd al-Hasanî (1564-1615). Later, Yesãrî Mehmed Es'ad (d. 1798), who was paralyzed on the right side and had to write with his left hand, found a new method for writing ta'liq by choosing what appealed to his taste from among the letters and words

\section{Resim/Picture 15}

Kadıasker Mustafa Izzet Efendi’nin Ayasofya Câmii için yazdığı çapı $7,5 \mathrm{~m}$. olan levhalardan biri $(1275 / 1859)$.

One of the plates dated 1275/1859 which Kãdıasker Mustafa Izzet Efendi calligraphed for Ayasofya Mosque. The diameter of the plate is $7,5 \mathrm{~m}$.

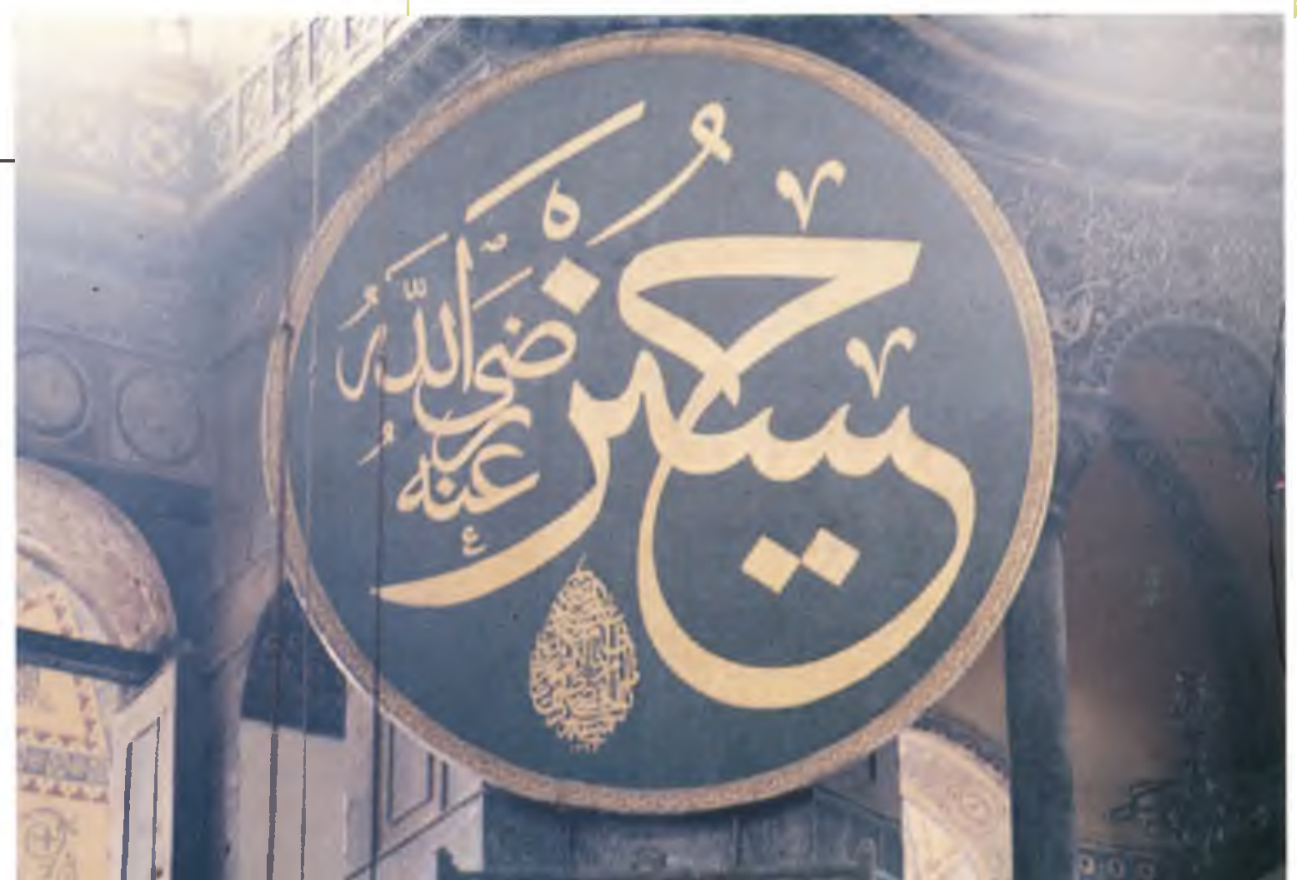




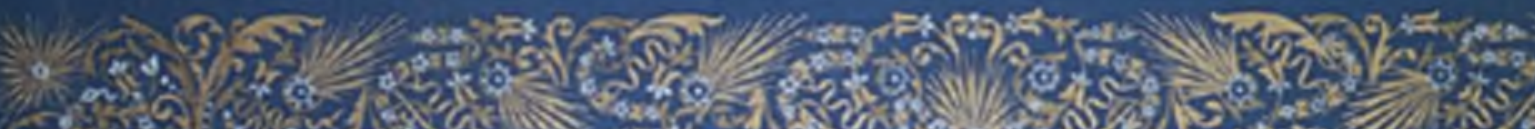

rex 19.6.

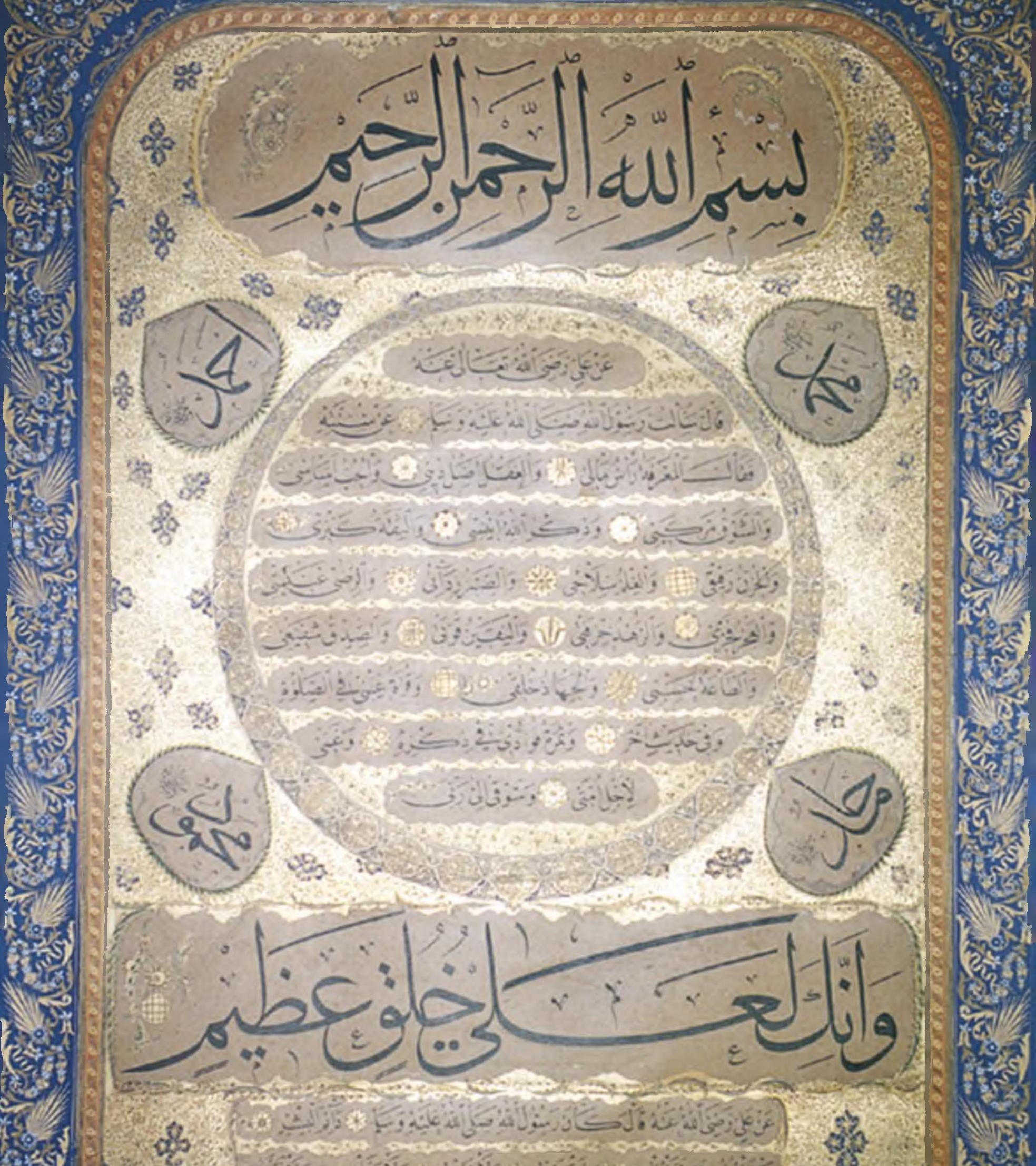

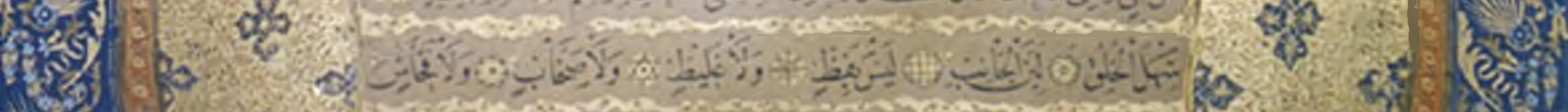

$N=0$

Q.

o.

42 
Resim/Picture 17

Yesârîzâde Mustafa lzzet Efendi'nin Istanbul'da Fatih Câmii yanındaki karakol binası için yazdığı celî ta lîk $^{\prime}$ kitâbe, ortada Sultan II. Mahmud'ın tuğrası görülüyor.

An inscription in jali ta'liq which Yesãrîzãde Mustafa Izzet Efendi calligraphed to be placed on the façade of the police station near Fatih Mosque. In the middle is seen Sultan Mahmud Il's tuğra.

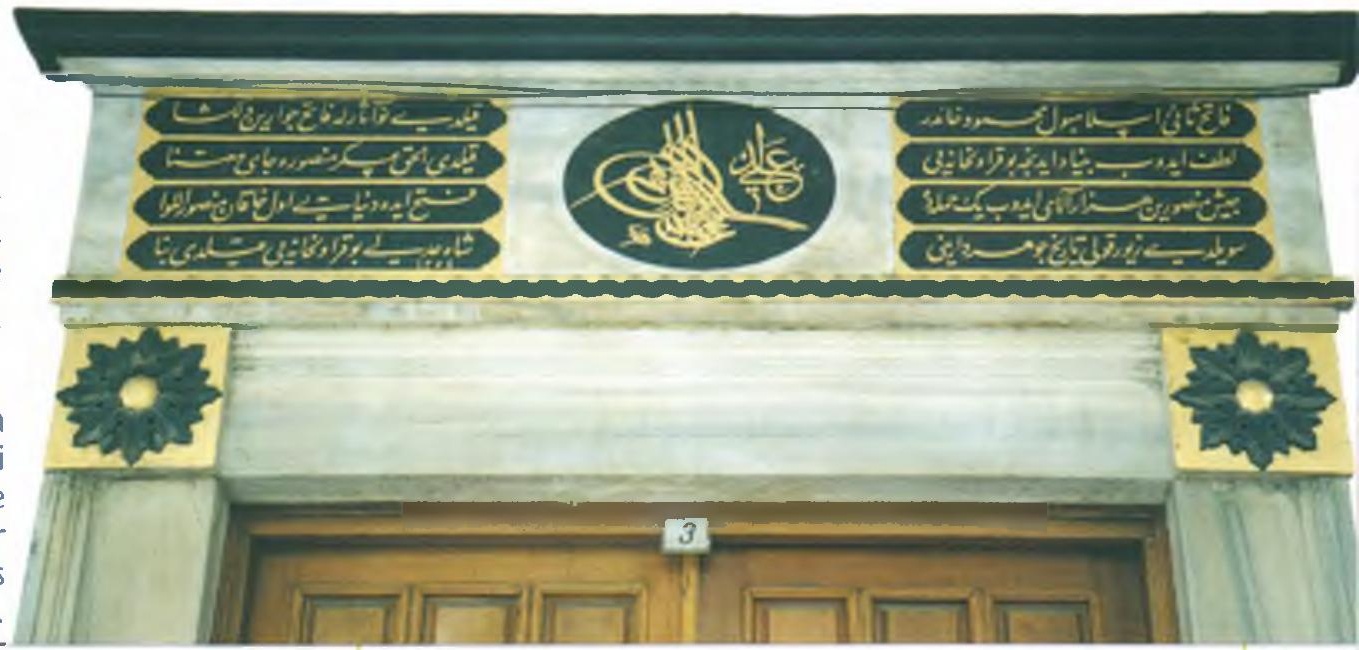

of Imãd (illustration 4). Yesãrî's son Yesãrîzade Mustafa Izzet (d.1849) adopted this style to the Ottoman taste (illustration 17). His inscriptions in jali ta'liq on buildings are of unsurpassed beauty. This script reached perfection at the hands of Sãmi Efendi (illustration 18).

The development of tuğra (illustration 17), diwãnî and jalî dîwãnî (illustration 19), which were used in official state correspondence, was completed in the nineteenth century. Let us note that there are some reasons which account for the continuous development of calligraphy until the twentieth century:

1. Among the branches of Islamic art, there is no art in Europe comparable to calligraphy, hence perhaps it is the only art that escaped Western influence. The Ottoman calligraphers transmitted this art to their students and to the next generation throughout the centuries on the basis of a firm method of teaching and without expecting money in return.

2 . In line with the tradition of the Prophet to the effect that "God is beautiful and loves beauty" (illustration 18), the Ottoman calligraphers felt the concept of "absolute beauty" in every line of calligraphy. Therefore, today their grandchildren are delighted to be able to mention "the art of Turkish calligraphy".

\section{esim/Picture 16}

ehmed Şevki Efendi'nin celî muhakkak, lî sülüs ve nesih hatları ile yazdığı ve lâm Peygamberi'nin hâricî ve ahlâkî sıflarını anlatan "hilye-i nebevî levhası" 282/1866 tarihli, Kāhire Millî itüphanesi).

hilye levha or panel in jali muhaqqaq, î thuluth and naskh by Mehmed Sevki endi. A description of the Prophet is ritten on these panels. (Dated 282/1866, National Library of Cairo)

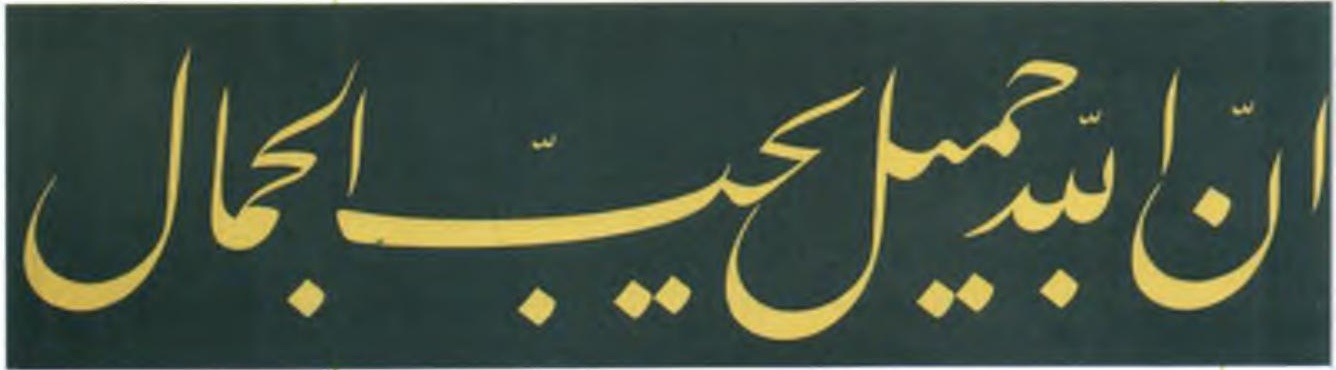

Resim/Picture 18

Sâmi Efendi'nin celî ta'lîk hattr ile "Allah güzeldir, güzelliği sever" hadîsi (Türkpetrol Vakfı Kütüphanesi). The work in jâi ta'fíq by Sãmi Efendi depicting the hadith: God is beautiful and loves beauty". (Türkpetrol Foundation Library).
Resim/Picture 19

Tuğrakeş Ismail Hakkı Altunbezer'in zer-endûd (=sürme altın) olarak yazdiğı celî dîvânî levha: "Elde altun bileziktir san'at / Ki verir ehline feyz ü rif'at".

A levha in jalî dîwãnî overlaid with gold by Tuğrakeş Ismail Hakkı Altunbezer: "Elde altun bileziktir san'at/ Ki verir ehline feyz ü rif'at= One can rely on a craft in all circumstances to earn one's living. Thanks to it, one prospers and gains eminence" (Topkapı Palace Museum Library).

Fotoğraflar/Photograps:

Hasan Âli Göksoy, Selâmet Taşkın, M.Uğur Derman,

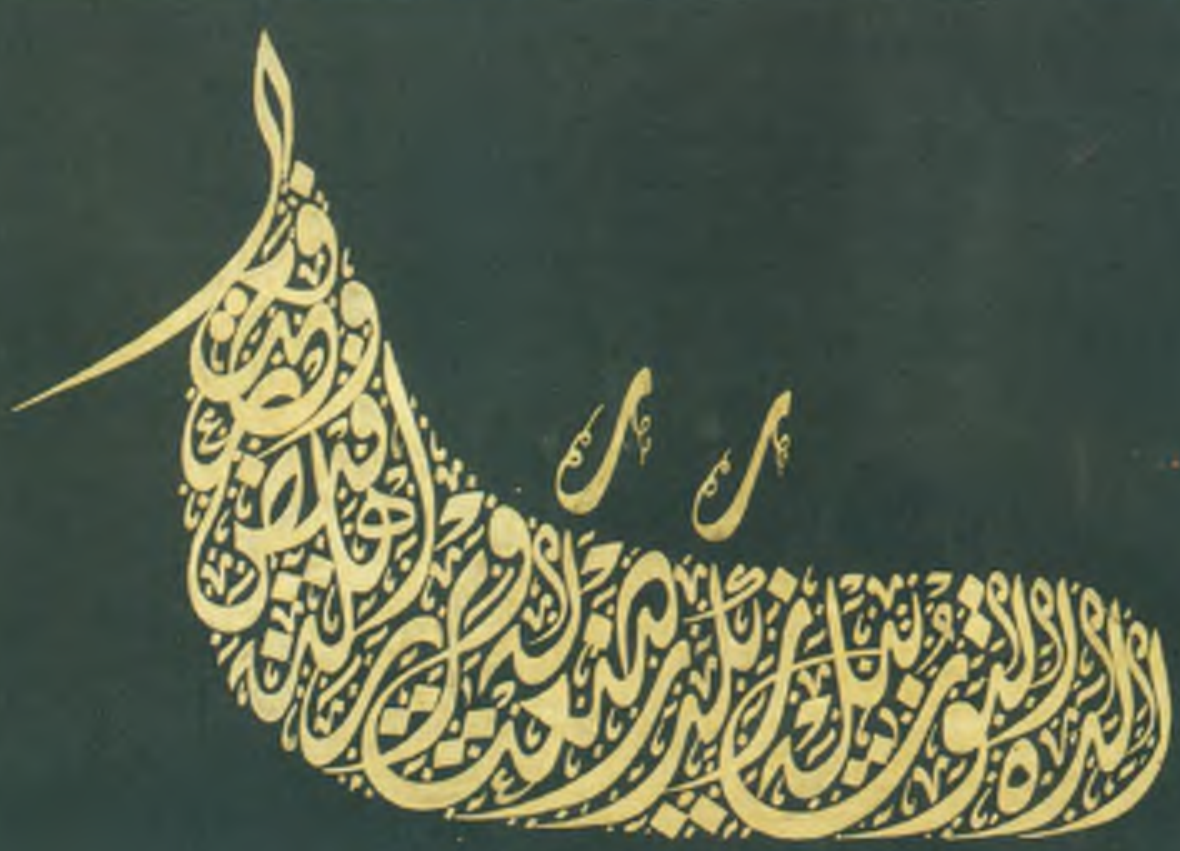

